\title{
A Review on Solar Thermal Utilization for Industrial Heating and Cooling Processes: Global and Ethiopian Perspective
}

\author{
Yacob Gebreyohannes ${ }^{1,2^{*}}$, Mulu Bayray ${ }^{1}$ and Johan Lauwaert ${ }^{2}$ \\ ${ }^{1}$ Thermal and Energy Systems chair, School of Mechanical and Industrial Engineering, Mekelle \\ University, Endayesus Campus, Mekelle, Ethiopia (*yacob.gebreyohannes@mu.edu.et). \\ ${ }^{2}$ Department of Electronics and Information Systems, Faculty of Engineering and Architecture, \\ Ghent University, iGent-tower, Technologiepark-Zwijnaarde 15, 9052 Ghent-Zwijnaarde.
}

\begin{abstract}
A substantial share of the total energy in various countries is consumed by industries and manufacturing sectors. Most of the energy is used for low and medium temperature process heating (up to $300^{\circ} \mathrm{C}$ ) as well as low and medium cooling capacity (up to $350 \mathrm{~kW}$ ). To meet the demand, the industrial sector consumes most of its energy in either thermal (heat) or electrical energy forms. The use of fossil fuels accounts for about half of the overall share. This resulted in a necessity to commercialize local and clean renewable energy sources efficiently considering the reduction of economic dependence on fossil fuels and greenhouse gases emission. As such, solar energy has proven potential and resulted in considerable development and deployment of solar heating industrial processes (SHIP) and solar cooling systems in recent times. Thus, an attempt to present a review of the available literature on overall energy intensiveness, process temperature levels, solar technology match, and solar thermal system performance and cost have been made in this paper. The review also includes identifying the potential and relevance of involving solar thermal for industrial heating and cooling demand. As a result, at least 624 SHIP including promising large-scale plants and 1350 solar cooling systems most of them in small and medium capacities in operation are identified. Though limited data is available for solar cooling potential and installation, investigations projected the global SHIP potential to 5.6 EJ for 2050. Consequently, given the presence of many low and medium temperature heating processes and cooling capacities in industries with immense solar energy potential, developing counties such as Ethiopia can take experience and pay attention to the development of sustainable industrial systems.
\end{abstract}

Keywords: Solar thermal, SHIP, Solar cooling, Potential, Relevance, Ethiopia.

\section{INTRODUCTION}

Now-a-days the global energy use is nearly 14,000 million tons of oil equivalent [Mtoe]. This is projected to increase by $48 \%$ in 2040 . A significant share, about $54 \%$, of the overall global energy use is reported for meeting industrial sector energy demand. On average, the global industrial sector energy consumption is projected to increase by $1.2 \%$ annually, from 222 to 309 quadrillion British thermal units [Btu] between 2012 and 2040. Depending on the availability of fuels and the technological choices for processes, the mix and share of energy sources used in the industrial sector vary across regions and countries. In the global context, the use of coal and liquid fuels 
accounts for about half of the overall share of fuels used in the industrial sector. As fossil fuel consumption raises, greenhouse gas emissions and $\mathrm{CO}_{2}$ - induced global warming have increased each year and become a pressing issue since the International Panel for Climate Change third assessment report. Without introducing an effective strategy, combustion-related emissions will increase by $50 \%$ in 2030 , and mitigation will become more challenging. Due to the geopolitically unstable supply area or lines and increasing trend of environmental awareness, the use of traditional energy is placed under strains and needs to be tackled (Gross and Otis, 2016; Diefenderfer et al., 2016; Mekhilef et al., 2011a; World Energy, 2011; Mekhilef et al., 2011b; US EIA, 2013; IPCC, 2001; Metz et al., 2007).

The efficient utilization of renewable energy resources, especially solar energy, is increasingly being considered as a promising solution to the supply and environmental burdens of traditional fuels. The upper atmosphere of the Earth receives an enormous amount of radiation energy $\left(340.4 \mathrm{~W} / \mathrm{m}^{2}\right)$ released from the Sun. This energy has been attenuated twice by both the atmosphere and the clouds ( $22.7 \%$ by atmosphere absorption, $22.6 \%$ by clouds and atmosphere reflection, and $6.7 \%$ by surface reflection). Of the total incoming solar radiation, the remained 48\% reaches the land and the oceans. Despite the attenuation, an enormous amount of the total solar energy is still available at the Earth's surface. The yearly global horizontal irradiation per unit area $\left(\mathrm{m}^{2}\right)$ ranges largely between 800 and $2700 \mathrm{kWh}$ depending on the geographic location (NASA, 2016; SOLARGIS, 2018).

Solar energy is widely used since ancient times by the Greeks and the Chinese to gain access to passive heating and light. Solar thermal [ST] technology represents a significant part of the global solar energy installed capacity. The abundance of solar radiation together with the state of art solar technologies, where the two essential subsystems are solar collectors and thermal energy storage, small- and large-scale heat energy demand have been well supplied despite the low-density and intermittency of solar radiation. This created favorable conditions for the exploitation of solar energy to meet the growing demand and reduce environmental effects. For example, the corresponding annual ST energy yield in 2017 amounted to $388 \mathrm{TWh}$, associates with a saving potential of 41.7 million tons of oil, and 134.7 million tons of $\mathrm{CO}_{2}$. Worldwide, the total operated ST capacity by the end of 2017 was $472 \mathrm{GW}_{\text {th }}$ followed by solar Photovoltaic [PV] $\left(402 \mathrm{GW}_{\mathrm{p}}\right)$, and Concentrating Solar Power $\left(5 \mathrm{GW}_{\mathrm{el}}\right)$. The installed capacity of ST raised by factor 7.6 compared to 2001 is at the top of an energy revolution which is inevitable to change power 
generation in the coming years (Smil, 1991; Shirazi et al., 2018; Weiss and Spörk-Dür, 2018; DeWinter, 1990; Zalba et al., 2003; Sharma et al., 2009; Alkilani et al., 2011).

Despite its achievements, the ST global market has been facing challenges in recent times especially in the large markets (China and Europe). There is market pressure from PV systems and heat pumps for traditional mass markets (small-scale solar water heating systems for single-family houses and apartment buildings). As such, a 4.2\% decline in the global market was recorded in 2017. However, positive market developments $26 \%$ in India, $7 \%$ in Mexico, and $4 \%$ in Turkey were also registered. As a result, ST is becoming a vital pillar of the present and future energy demand especially for large-scale heating and cooling applications (Shirazi et al., 2018; Weiss and Spörk-Dür, 2018; Taibi et al., 2012).

In contrast to the small-scale ST systems, the large-scale (megawatt solar heating and cooling) solutions supported by district heating systems and industrial applications have gained increasing interest all over the world. In the last couple of years, several ambitious projects have been successfully implemented (up to a capacity of $100 \mathrm{MW}_{\text {th }}$ ). At least 624 solar heat industrial processes [SHIP] and 1350 solar cooling systems were in operation at the end of 2017. Estimation of SHIP potential in different regions and countries with the consideration of required temperatures of specific processes and applications has been reported in various investigations. A global SHIP potential of approximately 5.6EJ for the year 2050 has been forecasted, with half of the potential being in the food and beverage sector. Other promising sectors identified were textiles and leather, pulp and paper production, automobile manufacturing, mining, and quarrying, etc. Solar cooling systems are also available for industrial applications. Though more and more players are entering the market (especially in Asia and the Middle East), data collection seems to be difficult and thus more recent global data are not available. Approximately $70 \%$ of the small and medium capacity ( $<350 \mathrm{~kW}$ ) solar cooling systems reported worldwide are installed in Europe (Shirazi et al., 2018; Weiss and Spörk-Dür, 2018; Taibi et al., 2012).

This paper presents a review of the potential, installation, and relevance aspects of solar thermal for the most important fields of application (heating and cooling). It also assesses the details of low and medium temperature levels heating and cooling capacity in the industrial sector energy use for the common industrial groupings. The review envisages achieving the most appropriate data across the globe and in Ethiopia to compare and outline valuable lessons. 


\section{POTENTIAL AND RELEVANCE OF ST FOR INDUSTRIAL APPLICATIONS}

A brief review on the global energy demand and cost of industries, solar thermal utilization and technologies, details of solar potential and industrial installations, and relevance of solar thermal (one of the objectives of the study) is presented in the following sections.

\subsection{Energy Demand and Cost of Industrial Groupings}

Depending on the level of industrial activities, the share of energy demand and cost varies considerably amongst different industries and countries. The world industrial sector can be categorized by three different industry types based on energy intensiveness and manufacturing products (Table 1).

Table 1. Major industry groups and representative industries (Gross and Otis, 2016).

\begin{tabular}{|c|c|c|}
\hline Industry type & Industry group & Representative manufacturing industries \\
\hline \multirow{7}{*}{$\begin{array}{l}\text { Energy-intensive } \\
\text { manufacturing }\end{array}$} & Food and beverage & Food, beverage, and tobacco products \\
\hline & Pulp and paper & Paper, printing, and related support activities \\
\hline & Basic chemicals & $\begin{array}{l}\text { Organic chemicals, inorganic chemicals, } \\
\text { agricultural chemicals, and resins }\end{array}$ \\
\hline & Refining & Petroleum refineries and coal products \\
\hline & Iron and steel & Iron and steel \\
\hline & Nonferrous metals & Aluminum, copper, zinc, and tin \\
\hline & Nonmetallic minerals & Cement, glass, lime, gypsum, clay \\
\hline \multirow[b]{2}{*}{$\begin{array}{l}\text { Nonenergy- } \\
\text { intensive } \\
\text { manufacturing }\end{array}$} & Other chemicals & $\begin{array}{l}\text { Pharmaceuticals (medicinal and botanical), } \\
\text { adhesives, detergents, paint and coatings, and } \\
\text { other miscellaneous chemical products }\end{array}$ \\
\hline & Other industrials & $\begin{array}{l}\text { All other industrial manufacturing including } \\
\text { metal-based durables (computer and electronic } \\
\text { products, electrical equipment, fabricated } \\
\text { metal products, machinery, and transportation } \\
\text { equipment) }\end{array}$ \\
\hline \multirow{3}{*}{ Nonmanufacturing } & $\begin{array}{l}\text { Agriculture, forestry, } \\
\text { fishing }\end{array}$ & Agriculture, forestry, and fishing \\
\hline & Mining & $\begin{array}{l}\text { Metallic and nonmetallic minerals mining, oil } \\
\text { and natural gas extraction, and Coal mining }\end{array}$ \\
\hline & Construction & $\begin{array}{l}\text { Buildings, heavy and civil engineering, and } \\
\text { industrial construction }\end{array}$ \\
\hline
\end{tabular}

The economic growth of countries is significantly affected by activities in the country's industrial sector. Long-term growth in industrial sector energy consumption occurs in most countries outside the Organization for Economic Cooperation and Development [OECD]. The 
total industrial sector energy use is projected to increase from 149 to 225 quadrillion Btu in the non-OECD countries and from 73 to 85 quadrillion Btu in the OECD countries between 2012 and 2040. The share of non-OECD countries' industrial energy consumption, which accounted for $67 \%$ of the world industrial sector delivered energy in 2012, is projected to account for $73 \%$ in 2040. However, the share of final energy use in the non-OECD industrial sector will decline from 2030 to 2040. This is because many emerging non-OECD economies (mainly China) will move away from energy-intensive manufacturing, more rapid energy use growth will be in all other end-use sectors (Gross and Otis, 2016)(bp, n.d.).

Table 2. Process temperature range and heat intensiveness by major groups of industry.

\begin{tabular}{|c|c|c|}
\hline Industry group & Process (es) & $\begin{array}{l}\text { Temperature range }\left({ }^{0} \mathrm{C}\right) \\
\text { Heat intensiveness }\end{array}$ \\
\hline $\begin{array}{l}\text { Steelmaking and other } \\
\text { casting industries }\end{array}$ & $\begin{array}{l}\text { Hardening, annealing, tempering, forging, } \\
\text { rolling }\end{array}$ & 700-1500 High \\
\hline Cement manufacturing & Lime calcining & 600-1200 High \\
\hline Automobile & $\begin{array}{l}\text { Paint pretreatment, baking of paints, paint } \\
\text { drying }\end{array}$ & 40-225 Low-Medium \\
\hline Plastics & $\begin{array}{l}\text { Preparation, distillation, separation, } \\
\text { extension, drying, blending }\end{array}$ & 120-220 Low-Medium \\
\hline $\begin{array}{l}\text { Chemical and } \\
\text { Pharmaceutical }\end{array}$ & $\begin{array}{l}\text { Distillation, evaporation, drying, } \\
\text { thickening }\end{array}$ & 100-200 Low-Medium \\
\hline Pulp and paper & $\begin{array}{l}\text { Bleaching, de-linking, drying, pulp } \\
\text { preparation, boiler feed water heating }\end{array}$ & 60-200 Low-Medium \\
\hline $\begin{array}{l}\text { Leather products, rubber, } \\
\text { plastic, and glass } \\
\text { manufacturing }\end{array}$ & $\begin{array}{l}\text { Pre-tanning, chrome tanning, drying and } \\
\text { finishing, drying (rubber), preheating, } \\
\text { preparation, distillation, extrusion, drying } \\
\text { (plastic), laminating, drying glass fiber }\end{array}$ & 40-200 Low-Medium \\
\hline Textile & $\begin{array}{l}\text { Blanching-drying, drying, degreasing, } \\
\text { pressing, fixing, printing }\end{array}$ & 40-180 Low-Medium \\
\hline Timber by-products & $\begin{array}{l}\text { Thermo-diffusion beams, drying, } \\
\text { preheating of water, preparation of pulp }\end{array}$ & 60-170 Low-Medium \\
\hline $\begin{array}{l}\text { Food processing, milk } \\
\text { processing, and } \\
\text { beverages production }\end{array}$ & $\begin{array}{l}\text { Cooking, pasteurization, sterilization, } \\
\text { tempering, drying, dehydration, washing, } \\
\text { cleaning, heat treatment }\end{array}$ & 40-150 Low \\
\hline Bricks and blocks & Curing & 60-140 Low \\
\hline Meat & Washing, sterilization, cooking & 60-100 Low \\
\hline
\end{tabular}

The industrial sector consumes most of its energy either in the form of thermal or electrical energy. Thermal energy is used in process heating applications (cooking, washing, dyeing, bleaching, drying, etc), whereas electrical energy is used for lighting, refrigeration, air 
conditioning, and operating motor drives. Process heating uses a significant share of energy demand in the industrial sector which varies with the industry, products being manufactured, types of processes, etc. It may be noted that process heating demand exists with varying temperature requirements in a large variety of industries for different processes (Table 2). Out of the total thermal energy demand, a major fraction (about 60\%) is reportedly in the temperature range of 30 - $250^{\circ} \mathrm{C}$ (US DoE, 2015; EECA, n.d.; Abdelaziz et al., 2010; Hasanuzzaman et al., 2012; Vignarooban et al., 2015; Pirasteh et al., 2014; Schweiger et al., 2015a; Eisentraut et al., 2014; Eia, 2014; Weiss \& Mauthner, 2011; Vannoni et al., 2008).

There is also increasing energy consumption for refrigeration and air conditioning, especially in the range of middle and small cooling capacities. In the last couple of decades, the dominant means for supplying cooling capacities have been compression refrigeration systems. These machines are driven by electrical energy. Another possibility for supplying cooling energy is the use of sorption refrigeration machines, which can be driven with thermal energy in the temperature range of $55-180^{\circ} \mathrm{C}$. Having been commercially available, absorption chillers are also mature and reliable technologies (Shirazi et al., 2018; Schweiger et al., 2015a; Hwang et al., 2008; Henkel, 2005).

Developments of energy prices are subjected to large uncertainties and most analyses of industrial energy use have been conducted at the national level. For example, in Cyprus, a cost analysis of the energy spent (fuels and electricity) by major groups of the industry during 1997 showed a considerable total value of money, about 27 million Cyprus pounds. The manufacture of non-metallic mineral products and food products, beverages, and tobacco were the types of industries that spent most of the energy (more than half of the overall share) (Kalogirou, 2003).

\subsection{ST Use and Technologies}

The present solar thermal use is subdivided into three main categories: low-, medium-, and high-temperature applications (Table 3). Several ST systems have been identified from several studies. Results of an attempt to provide the distribution of globally installed ST capacity are shown in table 4 (Weiss and Spörk-Dür, 2018). From several studies, it is very common that for active solar heating systems, solar collectors are the key components. The different characteristics of solar collectors are listed in table 5 . 
Table 3. The solar thermal use pattern (Fisch and Huckemann, 2006).

\begin{tabular}{|c|c|c|c|}
\hline Application & Low temperature $\left(<120^{\circ} \mathrm{C}\right)$ & $\begin{array}{l}\text { Medium } \\
\left(<400^{\circ} \mathrm{C}\right)\end{array} \quad$ temperature & $\begin{array}{l}\text { High } \\
\left(>400^{\circ} \mathrm{C}\right)\end{array}$ \\
\hline System & Low-temperature collector & Solar farm & Solar tower Solar furnace \\
\hline $\begin{array}{l}\text { Thermal } \\
\text { energy supply }\end{array}$ & $\begin{array}{l}\text { Swimming pool heating } \\
\text { Domestic hot water preparation } \\
\text { Space heating } \\
\text { Cooking } \\
\text { Drying } \\
\text { Distillation }\end{array}$ & $\begin{array}{l}\text { Process heat-desalting } \\
\text { Heating (waste heat) } \\
\text { Cooling } \\
\text { Air conditioning } \\
\text { Cooking }\end{array}$ & $\begin{array}{l}\text { Process heat-desalting } \\
\text { Heating (waste heat) } \\
\text { Cold generation } \\
\text { Air conditioning }\end{array}$ \\
\hline $\begin{array}{l}\text { Electric } \\
\text { energy supply }\end{array}$ & & $\begin{array}{l}\text { Water pumps } \\
\text { Light and TV }\end{array}$ & $\begin{array}{l}\text { Power generation } \\
\text { Hydrogen generation }\end{array}$ \\
\hline
\end{tabular}

Table 4. Total ST capacity in operation by region and country.

\begin{tabular}{|ll|}
\hline Region/Country & Installed Capacity $\left(\boldsymbol{G W}_{\text {th }}\right)$ \\
\hline China & 324.5 \\
\hline Europe & 51.8 \\
\hline USA and Canada & 18.6 \\
\hline Asia excluding China & 12.1 \\
\hline Latin America & 123 \\
\hline $\begin{array}{l}\text { MENA countries (Israel, Jordan, Lebanon, Morocco, Palestinian } \\
\text { territories, Tunisia) }\end{array}$ & 6.8 \\
\hline Australia and New Zealand & 6.5 \\
\hline $\begin{array}{l}\text { Sub-Sahara African countries (Botswana, Burkina Faso, Ghana, Lesotho, } \\
\text { Mauritius, Mozambique, Namibia, Senegal, South Africa, Zimbabwe) }\end{array}$ & 1.5 \\
\hline All other countries & 22.8 \\
\hline
\end{tabular}

Table 5. Solar energy collectors (Ben Hassine et al., 2014; Faninger, 2010; Islam et al., 2018).

\begin{tabular}{|c|c|c|c|c|}
\hline Motion & Collector type & $\begin{array}{l}\text { Absor- } \\
\text { ber type }\end{array}$ & $\begin{array}{l}\text { Concen- } \\
\text { tration ratio }^{I}\end{array}$ & $\begin{array}{l}\text { Indicative } \\
\text { temperature } \\
\text { range }\left({ }^{\circ} \mathrm{C}\right)\end{array}$ \\
\hline \multirow{3}{*}{$\begin{array}{l}\text { Stationary } \\
\text { (Fixed and } \\
\text { seasonal tilt) }\end{array}$} & $\begin{array}{l}\text { Standard Flat Plate Collector (SFPC) } \\
\text { Evacuated Flat Plate Collector (EFPC) }\end{array}$ & Flat & 1 (non-oncentrating) & $30-80$ \\
\hline & Evacuated Tube Collector (ETC) & Flat & 1 (non-oncentrating) & $50-200$ \\
\hline & Compound Parabolic Collector (CPC) & $\begin{array}{l}\text { Flat/ } \\
\text { Tubular }\end{array}$ & $\begin{array}{l}1-5 / 5-15 \text { (low- } \\
\text { concentrating) }\end{array}$ & $\begin{array}{l}60-240 / \\
60-300 \\
\end{array}$ \\
\hline \multirow{3}{*}{$\begin{array}{l}\text { Single-axis } \\
\text { tracking }\end{array}$} & Fresnel Lens Collector (FLC) & Tubular & $10-40$ (concentrating) & $60-250$ \\
\hline & Parabolic Trough Collector (PTC) & Tubular & 15-45 (concentrating) & $60-300$ \\
\hline & Cylindrical Trough Collector (CTC) & Tubular & 10-50 (concentrating) & $60-300$ \\
\hline \multirow[t]{2}{*}{$\begin{array}{l}\text { Two-axes } \\
\text { tracking }\end{array}$} & Parabolic Dish Reflector (PDR) & Point & $\begin{array}{l}\text { 100-1000 (high- } \\
\text { concentrating) }\end{array}$ & $100-500$ \\
\hline & Heliostat Field Collector (HFC) & Point & $\begin{array}{l}\text { 100-1500 (high- } \\
\text { concentrating) }\end{array}$ & $150-2000$ \\
\hline
\end{tabular}

Note: ${ }^{1}$ concentration ratio is defined as the ratio of aperture area to the receiver/absorber area of the collector. 
In a global context, evacuated tube collectors were the predominant ST collector technology with a share of $(71.6 \%)$ followed by flat plate collectors $(22.1 \%)$, unglazed water collectors $(6.1 \%)$, and glazed and unglazed air collectors $(0.3 \%)$. This breakdown is mainly driven by the dominance of the Chinese market where around $86 \%$ of all newly installed collectors in 2016 being evacuated tube collectors. The situation in Europe is almost the opposite compared to China with $74.9 \%$ of newly installed collectors were flat plate collectors. Yet, it is notable that the global share of evacuated tube collectors declined from about $82 \%$ in 2011 to $73.8 \%$ in 2016, and in the same period flat plate collectors increased the share from $14.7 \%$ to $22.1 \%$ (Weiss and SpörkDür, 2018).

From several studies, absorption chiller technology is considered the most desirable method for ST cooling and is expected to compete at scale with conventional systems in the foreseeable future. Absorption chillers are categorized by the cooling effects (number of times heat is recycled inside the chiller to produce cooling). Typically, there are three types of absorption chillers commercially available on the market: single-, double-, and triple-effect chillers. Moving towards a higher effect provides a higher coefficient of performance (COP), but requires higher driving temperatures and a more complicated cycle (Shirazi et al., 2018). The absorption chillersolar thermal collector matching is shown in table 6.

Table 6. Absorption chiller-solar thermal collector matching

\begin{tabular}{|c|c|c|}
\hline Chiller type & Nominal operating temperature $\left({ }^{0} \mathrm{C}\right)$ & Collector type \\
\hline Single-effect & $80-100$ & $\begin{array}{l}\text { Flat Plate Collector } \\
\text { Evacuated Tube Collector }\end{array}$ \\
\hline Double-effect & $180-200$ & $\begin{array}{l}\text { Linear Fresnel Reflector } \\
\text { Evacuated Flat Plate Collector } \\
\text { Parabolic Trough Collector }\end{array}$ \\
\hline Triple-effect & $210-240$ & Parabolic Trough Collector \\
\hline
\end{tabular}

\subsection{Potential and Installations of ST for Industrial Applications}

Estimation of SHIP potential in different regions and countries with the consideration of required temperatures of specific processes and applications has been reported in various investigations. A global SHIP potential of approximately 5.6EJ for the year 2050 has been forecasted with half of the potential being in the food and beverage sector. Other promising manufacturing sectors identified were textiles and leather, pulp and paper, automobile, mining, and quarrying, etc. Various assessments aiming at the estimation of SHIP potential focusing on individual industries 
of a specific region or country have also been reported. For example, an annual potential of 260PJ has been estimated in EU-28 for industries in food products, tobacco products, wine and beverages, beer and malt, textile, leather, pulp and paper, chemicals, machinery, and automobile. Similarly, a SHIP potential of 25PJ has been estimated for the paper industry in India whereas the estimated SHIP potential in the dairy industry of India is 6.40PJ (Taibi et al., 2012; Vannoni et al., 2008; Sharma et al., 2015; Sharma et al., 2017a). A summary of some of the estimations reported in the literature is grouped by region and listed in table 7 .

Table 7. Estimates of SHIP potential in some countries.

\begin{tabular}{|c|c|c|c|c|c|}
\hline $\begin{array}{l}\text { Region } \\
\text { Country }\end{array}$ & $\begin{array}{l}\text { Industrial sectors included } \\
\text { for potential estimation }\end{array}$ & $\begin{array}{l}\text { Temperature } \\
\text { range selected } \\
\left({ }^{\circ} \mathrm{C}\right)\end{array}$ & $\begin{array}{l}\text { SHIP } \\
\text { potential } \\
\text { (PJ/year) }\end{array}$ & $\begin{array}{l}\text { Collector area } \\
\left(\text { million } m^{2}\right)\end{array}$ & Reference \\
\hline \multicolumn{6}{|l|}{ Europe } \\
\hline Germany & $\begin{array}{l}\text { Food products, wine, and } \\
\text { beverages, textile, rubber } \\
\text { and plastic chemicals, pulp } \\
\text { and paper, manufacturing }\end{array}$ & Up to 300 & 57.6 & & $\begin{array}{l}\text { (Lauterbach } \\
\text { et al., 2012) }\end{array}$ \\
\hline Italy & $\begin{array}{l}\text { Food products, wine, and } \\
\text { beverages, beer and malt, } \\
\text { textile, leather, chemicals, } \\
\text { machinery and automobile, } \\
\text { pulp and paper, tobacco } \\
\text { products }\end{array}$ & Up to 300 & 31.8 & 14.3 & $\begin{array}{l}\text { (Vannoni et } \\
\text { al., 2008) }\end{array}$ \\
\hline Austria & $\begin{array}{l}\text { Food products, wine and } \\
\text { beverages, beer and malt, } \\
\text { textile, machinery, and } \\
\text { automobile }\end{array}$ & Up to 250 & 5.4 & 4.3 & $\begin{array}{l}\text { (Vannoni } \\
\text { et al., 2008) }\end{array}$ \\
\hline Spain & $\begin{array}{l}\text { Food products, wine, and } \\
\text { beverages, beer and malt, } \\
\text { textile, chemicals, pulp and } \\
\text { paper, tobacco products }\end{array}$ & Up to 160 & 17 & $8-10$ & $\begin{array}{l}\text { (Nathan and } \\
\text { Scobell, } \\
\text { 2012) }\end{array}$ \\
\hline Portugal & $\begin{array}{l}\text { Food products, wine, and } \\
\text { beverages, beer and malt, } \\
\text { textile, chemicals, pulp and } \\
\text { paper, tobacco products }\end{array}$ & Up to 160 & 4 & $1.9-2.5$ & $\begin{array}{l}\text { (Nathan and } \\
\text { Scobell, } \\
\text { 2012) }\end{array}$ \\
\hline Greece & $\begin{array}{l}\text { Chemicals, food and } \\
\text { beverages, tobacco, paper, } \\
\text { textiles, lase and transport } \\
\text { equipment }\end{array}$ & Up to 100 & 0.21 & 0.015 & $\begin{array}{l}\text { (Vannoni et } \\
\text { al., 2008) }\end{array}$ \\
\hline $\begin{array}{l}\text { Nether- } \\
\text { lands }\end{array}$ & $\begin{array}{l}\text { Food products, wine, and } \\
\text { beverages, beer and malt, } \\
\text { textile, leather, pulp, and } \\
\text { paper }\end{array}$ & Up to 60 & 1.95 & $0.8-1$ & $\begin{array}{l}\text { (Taibi et al., } \\
\text { 2012) }\end{array}$ \\
\hline Asia & & & & & \\
\hline
\end{tabular}




\begin{tabular}{|c|c|c|c|c|c|}
\hline \multirow[t]{4}{*}{ India } & $\begin{array}{l}\text { Textile, paper, food } \\
\text { processing, dairy, } \\
\text { automobile, laser }\end{array}$ & $50-250$ & \multicolumn{2}{|l|}{24.75} & $\begin{array}{l}\text { (ABPS, } \\
2011)\end{array}$ \\
\hline & Paper & $50-250$ & 25 & 1.83 & $\begin{array}{l}\text { (Sharma et } \\
\text { al., 2015) }\end{array}$ \\
\hline & Cotton based textiles & $40-250$ & 91 & & $\begin{array}{l}\text { (Sharma et } \\
\text { al., 2017b) }\end{array}$ \\
\hline & Dairy & Up to 200 & 6.4 & 1.11 & $\begin{array}{l}\text { (Sharma et } \\
\text { al., 2017a) }\end{array}$ \\
\hline Pakistan & $\begin{array}{l}\text { Textile, surface treatment, } \\
\text { food, chemical, and leather }\end{array}$ & Below 100 & 20.41 & 7.1 & $\begin{array}{l}\text { (Hoffmann } \\
\text { and Kogler, } \\
\text { 2014) }\end{array}$ \\
\hline \multicolumn{6}{|c|}{ Latin America } \\
\hline Chile & $\begin{array}{l}\text { Food, paper and cellulose, } \\
\text { wood }\end{array}$ & Below 250 & 25.92 & 9 & $\begin{array}{l}\text { (Platzer, } \\
\text { 2015) }\end{array}$ \\
\hline Mexico & Food and textile & $60-160$ & 28.5 & & $\begin{array}{l}\text { (Ramos et } \\
\text { al., 2014) }\end{array}$ \\
\hline \multicolumn{6}{|l|}{ Africa } \\
\hline Morocco & $\begin{array}{l}\text { Surface treatment, food } \\
\text { chemical, textile and leather }\end{array}$ & Below 100 & 61 & 23 & $\begin{array}{l}\text { (Hoffmann } \\
\text { and Kogler, } \\
\text { 2014) }\end{array}$ \\
\hline Egypt & $\begin{array}{l}\text { Chemical, food textile, and } \\
\text { agriculture }\end{array}$ & Below 100 & 16.42 & 4.6 & $\begin{array}{l}\text { (Hoffmann } \\
\text { and Kogler, } \\
\text { 2014) }\end{array}$ \\
\hline
\end{tabular}

Many promising projects on SHIP have been implemented ranging from small-scale demonstration plants to very large systems capacities. In 2017, operating 124 new SHIP installations, totaling $192,580 \mathrm{~m}^{2}$ collector area is started. This increased the documented world total SHIP system by $25 \%$ in the number of installed plants and by $46 \%$ in the installed collector area. At least 624 SHIP systems, totaling $608,994 \mathrm{~m}^{2}$ collector areas were in operation at the end of 2017. The world's largest SHIP application, located at the Amal oilfield in the south of the Sultanate of Oman, began operation in February 2018. The Miraah parabolic trough plant with a total capacity of over $100 \mathrm{MW}_{\text {th }}$ delivers 660 tons of steam per day for the extraction of viscous or heavy oil as an alternative to steam generated from natural gas. Compared to the estimated potential for SHIP, the existing level of penetration in the industry is very small. However, there is increasing use of megawatt solar heating solutions as shown in figure 1 (Weiss and Spörk-Dür, 2018; ESTIF, 2006; Schweiger et al., 2015b).

By the end of 2018, the solar heat worldwide report investigated the details of around 271 operating systems with a total capacity of about $214 \mathrm{MW}_{\text {th }}$, totaling about $425,000 \mathrm{~m}^{2}$ collector 
area. Many of these systems are experimental and are relatively small-scale pilot projects. Only 28 plants have solar collector areas of more than $1000 \mathrm{~m}^{2}$ (Weiss and Spörk-Dür, 2018).

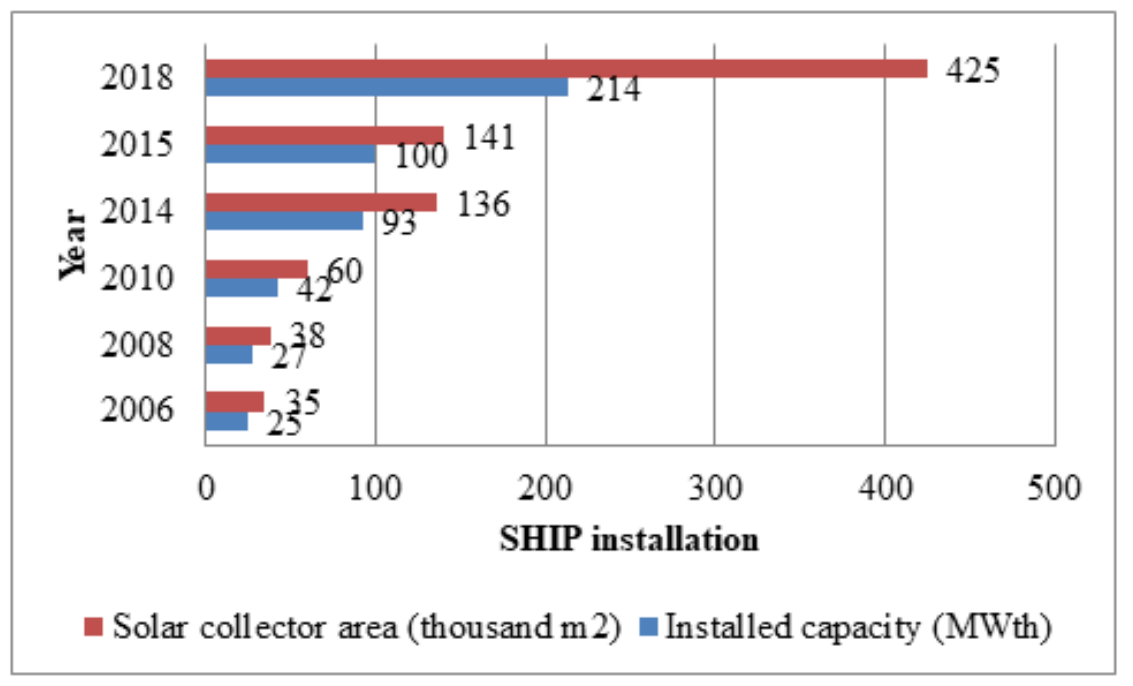

Figure 1. Time-trend of reported global installed capacity of SHIP systems.

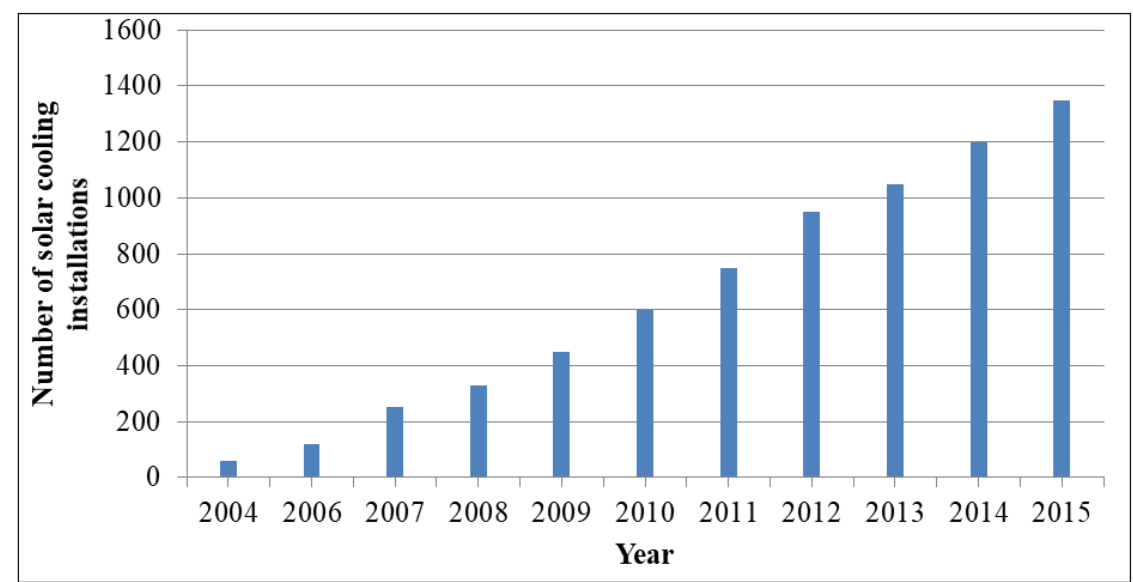

Figure 2. Estimated number of solar cooling systems installed across the world.

Solar cooling systems are also available for industrial applications. Though more and more players are entering the market (especially in Asia and the Middle East), data collection seems to be difficult and thus more recent global data are not available. However, there is increasing use of solar cooling solutions for large public and private buildings as well as factories as shown in figure 2 (Shirazi et al., 2018; Weiss and Spörk-Dür, 2018).

By the end of 2015, an estimated 1,350 solar cooling systems were installed worldwide. Approximately $70 \%$ of the small and medium capacity $(<350 \mathrm{~kW})$ solar cooling systems worldwide are installed in Europe (Shirazi et al., 2018; Weiss and Spörk-Dür, 2018). 


\subsection{Ranking and Details of ST Installed Plants}

The ranking and share of the top three industry sectors, collector types, and countries in terms of the number of plants and installed power in 2018 are listed in table 8 (Weiss and Spörk-Dür, 2018). The result of an attempt to provide details of some globally installed food and beverage SHIP plants, as per the information available in the literature, is presented in table 9 (SHIP, n.d.).

Table 8. Ranking of top three installed SHIP plants.

\begin{tabular}{|llll|}
\hline Number of plats/Installed capacity $\left.\mathbf{M W}_{\text {th }}\right)$ & $\begin{array}{l}\text { Installed capacity } \\
\text { plants }\end{array}$ & $\left.\mathbf{M W}_{\text {th }}\right)$ / Number & \\
\hline Industry sector & & & \\
\hline Food & $104 / 33$ & Mining & $131 / 14$ \\
Beverage & $28 / 66$ & Beverage & $66 / 28$ \\
Textile & $23 / 22$ & Food & $33 / 104$ \\
\hline Collector type & & & \\
\hline Flat plate & $124 / 71$ & Parabolic trough & $111 / 49$ \\
Parabolic & trough & $71 / 124$ \\
Evacuated tube & $49 / 111$ & Flat plate & $18 / 46$ \\
\hline Country & $46 / 18$ & Evacuated tube & \\
\hline $\begin{array}{l}\text { Mexico } \\
\text { India }\end{array}$ & & & $100 / 1$ \\
Austria & $65 / 14$ & Oman & $27 / 2$ \\
\end{tabular}

Table 9. Details of some food and beverage SHIP system reported globally in 2018.

\begin{tabular}{|llllll|}
\hline Location & Industry & Application & $\begin{array}{l}\text { Installed } \\
\text { capacity } \\
\left(\boldsymbol{M W}_{\text {th }}\right)\end{array}$ & $\begin{array}{l}\text { Heat } \\
\text { transfer } \\
\text { media }\end{array}$ & $\begin{array}{l}\text { Solar } \\
\text { collector }\end{array}$ \\
\hline Tamil Nadu, India & Hatsun Dairy & $\begin{array}{l}\text { Steam supply of a } \\
\text { dairy drying }\end{array}$ & 320.0 & thermo-oil & PTC \\
\hline Limassol, Cyprus & KEAN Soft Drinks Ltd & $\begin{array}{l}\text { Steam supply of a } \\
\text { fruit juice } \\
\text { manufactory }\end{array}$ & 201.6 & Steam & PTC \\
\hline $\begin{array}{l}\text { Ciudad de } \\
\text { México, Mexico }\end{array}$ & KOF MIXCOAC & & 87.5 & Water & FPC \\
\hline $\begin{array}{l}\text { Ciudad de } \\
\text { México, Mexico }\end{array}$ & INDUSTRIA DEL & $\begin{array}{l}\text { Preheat of water for } \\
\text { cooking }\end{array}$ & 50.4 & Water & FPC \\
\hline $\begin{array}{l}\text { México D.F., } \\
\text { Mexico }\end{array}$ & INDUSTRIA MAIZ & $\begin{array}{l}\text { Preheat of water for } \\
\text { cooking }\end{array}$ & 50.4 & Water & FPC \\
\hline $\begin{array}{l}\text { Ciudad de } \\
\text { México, Mexico }\end{array}$ & SAN PABLO VILLA & $\begin{array}{l}\text { Preheat of hot water } \\
\text { for cooking }\end{array}$ & 49.0 & Water & FPC \\
\hline $\begin{array}{l}\text { Tlalnepantla, } \\
\text { Mexico }\end{array}$ & KACTORY TOR & Heating of makeup & 31.5 & Water & FPC \\
\hline
\end{tabular}




\subsection{Performance and costs of ST for industrial application}

The capacity factors for ST systems are highly region-specific and can range from 4\% (e.g. Japan) to 16 - 20\% (e.g. UAE/India) to $29 \%$ (e.g. Mexico). The total investment costs for ST systems, with few exceptions and differences at the national level range from EUR $180-500 / \mathrm{m}^{2}$. This equates to solar thermal systems in the range of EUR $450-1100 / \mathrm{kW}_{\text {th }}$ and leads to an average energy cost of EUR $0.02-0.05 / \mathrm{kWh}$ for low-temperature and EUR $0.05-0.15 / \mathrm{kWh}$ for mediumtemperature applications (Schweiger et al., 2015a). The result of an attempt to provide details of some globally installed SHIP plants, as per the information available in the literature, is presented in table 10.

Table 10. Investment cost per $\mathrm{kW}_{\text {th }}$ for selected SHIP in operation after 2010.

\begin{tabular}{|lllll|}
\hline Country & $\begin{array}{l}\text { Year of } \\
\text { installation }\end{array}$ & Collector type & $\begin{array}{l}\text { Installed capacity } \\
\left(\boldsymbol{k} \boldsymbol{W}_{\text {th }}\right)\end{array}$ & $\begin{array}{l}\text { Cost } \\
(\text { Euro/kW } \boldsymbol{t h})\end{array}$ \\
\hline Vietnam & 2012 & ETC & 494 & 91 \\
\hline India & 2011 & ETC & $97-369$ & 203 \\
\cline { 2 - 5 } & 2011 & FPC & $84-302$ & 216 \\
\hline Turkey & 2013 & FPC & 490 & 237 \\
\hline Austria & 2013 & FPC & 1064 & 271 \\
\hline China & 2012 & ETC & 441 & 272 \\
\hline Germany & 2010 & FPC & 400 & 523 \\
\hline Israel & 2014 & FPC & 30.5 & 744 \\
\hline Spain & 2011 & FPC & 176 & 1373 \\
\hline USA & 2012 & FPC & 5462 &
\end{tabular}

\subsection{Relevance of ST Systems for Industrial Application}

As discussed earlier, the fuel mix for the industrial sector is dominated by the use of fossil fuels. Therefore, it is desirable to reduce fossil fuel consumption while meeting the increasing energy demand of the industrial sector. A reduction in the consumption of fossil fuels in the industrial sector can be achieved by (i) improving the utilization efficiency of fuel and electricity in various processes and equipment, (ii) harnessing renewable and environmentally clean sources of energy such as solar energy as a substitution of fossil fuel in suitable processes and end-uses. Energy efficiency improvements are necessary to provide substantial benefits in the short term. To provide multiple benefits in the long run, harnessing renewable energy sources to meet the industrial energy demand is the best option. This will have dual benefits by reducing the burden on fossil fuels (inter-generational equity and import dependence) and lowering greenhouse gas emissions 
(global warming) (Abdelaziz et al., 2010; Saidur et al., 2009; Saidur, 2010; Gautam et al., 2017; Batidzirai et al., 2009; Benli, 2016; Sharma et al., 2014).

Similarly, as discussed in the previous sections, a significant share of the heat demand in the industries is in the low- and medium-temperature range $\left(50-300^{\circ} \mathrm{C}\right)$. Besides, industries demand mainly small to medium cooling capacities ( $<350 \mathrm{~kW})$. Therefore, this heating and cooling demand could be well supplied with the state of art solar technologies. Hence, industrial solar heating and cooling [ISHC] is one of the promising options to meet the increasing industrial energy demand especially in oil-importing countries (Weiss and Spörk-Dür, 2018; Vajen et al., 2012; Rashad et al., 2013).

Solar energy can be used to produce electricity or heat for the ISHC application. However, the conversion of solar energy into thermal energy can have much higher efficiency (up to 70\%) as compared to the efficiency of producing electricity from solar energy. For example, the efficiency of ST power generation is reported between 20-25\% while for PV conversion the corresponding values are between 15-20\% (Rashad et al., 2013; Chu, 2011; Byrne, 2010).

On the other hand, the price of solar PV cells has dramatically decreased in recent years and has relatively simple and low maintenance. However, its production is limited to sunny hours due to the high cost of battery storage. It should be noted that much thermal storage capacity is required to meet the capacity of an electrical storage system. Therefore, PV technology is suitable only for small-scale applications. For example, ST cooling systems are less likely to be taken up at residential scales due to their significantly higher price tag compared to conventional gridconnected or PV systems. For large-scale applications, however, economies of scale can make larger units more financially viable. Another advantage of thermal-driven cooling systems is that by removing the mechanical compressor, they are characterized by low vibration and low noise operation as well as the use of natural refrigerants, such as water and ammonia. Moreover, in regions that require both heating and cooling throughout a year, ST systems represent a year-round solution, improving the system efficiency and economics as compared to those producing either heat or cold alone (Shirazi et al., 2018).

\section{POTENTIAL AND RELEVANCE OF ST FOR INDUSTRIAL APPLICATION IN ETHIOPIA}

A brief review of the industrial sector situation, energy profile, and solar potential and installations in Ethiopia (as one of the objectives of the study) is presented in the following sections. 


\subsection{Industrial Sector Economic and Energy Situation in Ethiopia}

The medium and large-scale manufacturing sector accounts for $70 \%$ of the industrial sector in Ethiopia. Within the manufacturing sector, the agro-processing (food and beverage) subsector, the textile and apparel industry, and the manufacturing of non-metallic mineral products are the most important industries. The food and beverage subsector products (Sugar and confectionary, Malt liquors and malt, Flour, and Soft drinks) have been in the top ten products at least for the last 15 years (MoI, 2017; Gebreeyesus, 2013, Encyclopedia, n.d.; Eshetie, 2018).

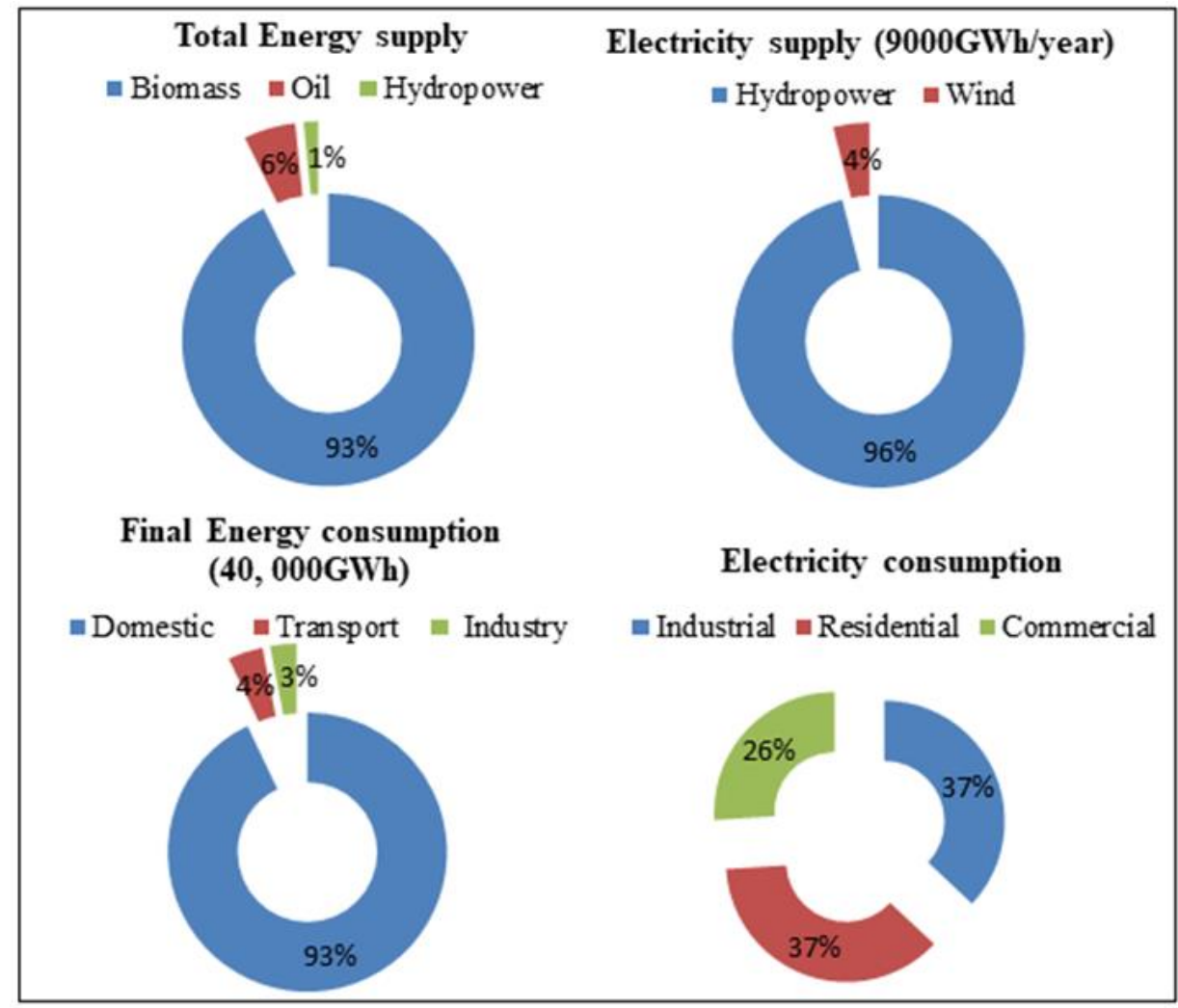

Figure 3. Ethiopia's energy supply and consumption by fuel and sector type (Energypedia, 2013; FDRE, 2013).

The statistic in the share of economic sectors for the gross domestic product [GDP] in Ethiopia from 2007 to 2017 resulted in the rise of industrial sector contribution from 11.59 to $22.9 \%$ within ten years. The overall goal of the industrial development strategy is aimed at increasing the share of the industry sector and the manufacturing sector as a percentage of the GDP to reach $27 \%$ and $17 \%$ respectively by 2025 . As such, developing manufacturing in sectors where Ethiopia has a comparative advantage and establishment of industrial zones in different parts of the country has been considered as the strategic direction in promoting the country's industrial 
development. With this objective, the government has taken several measures including furnishing the industrial estates with necessary power supply infrastructures (Statista, 2018; MoI, 2017, MoFED, 2014; Indexmundi, 2019; Gebreeyesus, 2013). Ethiopia's main energy supply and consumption profile are shown in figure 3 .

\subsection{Solar Resource Potential and Installations in Ethiopia}

Ethiopia has great potential for solar energy as it receives solar irradiation of $5-7 \mathrm{kWh} / \mathrm{m}^{2}$ for 5 8 hours for most of the year depending on the locale and the season. The average solar radiation is $5.2 \mathrm{kWh} / \mathrm{m}^{2} /$ day. The values vary with the seasons (dry and wet) and over space (west and east) as shown in figure 4.

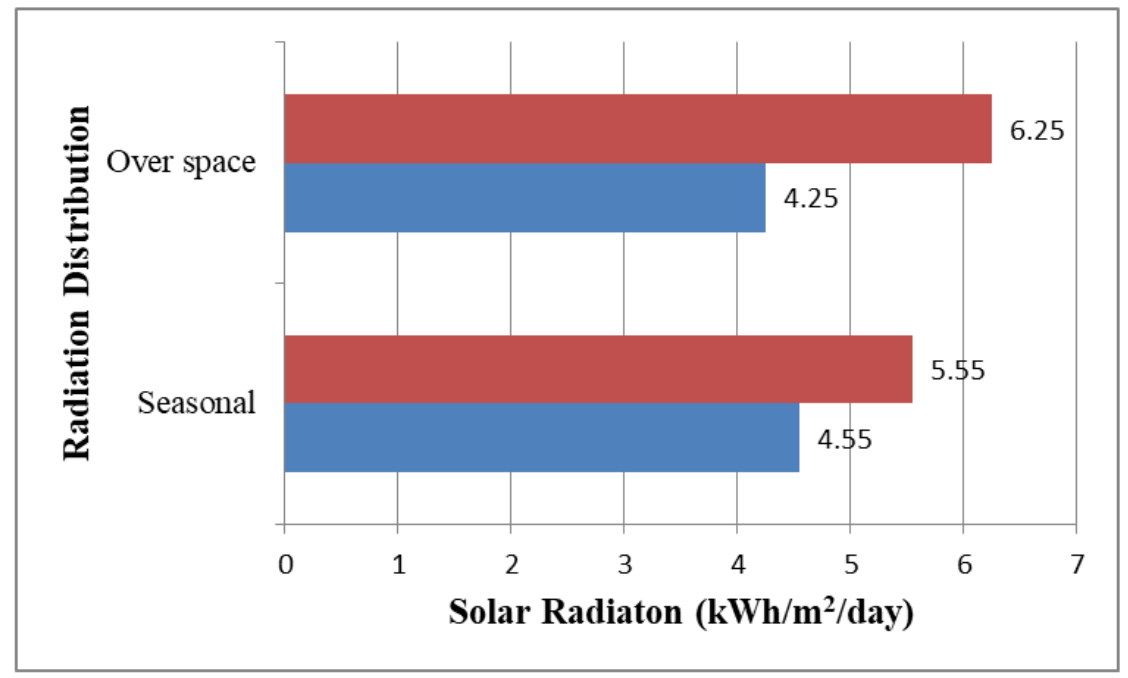

Figure 4. Ethiopia's range of annual global horizontal solar radiation.

In Ethiopia, the installed solar capacity in 2011 was approximately 5 MW. Though still small, the solar generation focuses on PV electricity generation for the solar home system (SHS), health centers, and telecommunication sectors (Energypedia, 2013; REEP, n.d.; UNEP, 2015; Ethio-Resource-Group, 2012).

\subsection{Potential and installations of $\mathrm{ST}$ for industrial application in Ethiopia}

The overall goal of industrial development is to contribute to Ethiopia's annual economic growth. This trend of economic growth would result in an expected rise in energy demand by a rate of 10 - 14\% per year until 2037. With an increasing load, the power system in the country has been facing more frequent, widely spread, and long-lasting blackouts. Besides, the volume of petroleum imports has been growing rapidly ( $8 \%$ annually and higher) over the past 10 years which increased 
the burden on trade balance and ecology. Considering these as the major challenges in realizing Ethiopia's industrialization vision, the country plans to increase installed power generation capacity, up from 2, $000 \mathrm{MW}$ to $10,320 \mathrm{MW}$, by building major hydro-dams and expanding to other sources of renewable energy. As such, the utilization of solar energy can be quite effective in the country because most regions in Ethiopia experience more or less uniform solar radiation (Energypedia, 2013; FDRE, 2013; Alemu, 2017).

\section{SUMMARY AND FUTURE RESEARCH SCOPE}

The first part of this paper summarizes recent works of literature on major global industrial groupings, energy intensiveness and demand, energy mix, and energy cost. It also reviews different aspects of the ST system for ISHC applications such as its potential, technology, performance, cost, and relevance. Following that, a survey of typical SHIP and solar cooling systems in operation is summarized to give extensive information on its development and status. Similarly, the second part tries to review the details of Ethiopia's industry, energy, and solar resource and installation profiles.

Both parts show the increase in the trend of industrial energy demand in developing countries and the dominance of food and beverage industries in total production, thereby, energy demand and cost. The similarity in the existing energy mix for industrial processes (fossil fuels and electricity) is also observed. However, attempts for sustainable energy development in future industries by reducing the consumption of non-renewable fuels and involving solar energy to supply both process heating and cooling demand in manufacturing industries and thereby reducing the economic and environmental effects are limited to developed countries.

To exploit the potential that exists, a significant opportunity for solar energy augmentation can be complemented using the available solar technologies and the high share of heat demand in the varying low to medium temperature levels $\left(30-250^{\circ} \mathrm{C}\right)$ of processes and the need for low cooling capacity $(<350 \mathrm{~kW})$ in industries. Moreover, ST becomes attractive for large-scale energy production with improved efficiency, economics, and dispatch ability. With this capacity, ISHC was observed to have a large potential with a high number of low- and medium-temperature solar collector installations.

Despite the potential and available technology, supplying ST energy to run industrial processes is still very limited in operation. The major drawbacks of a lack of implementing ISHC 
systems are the considerable capital cost of installation and uncertainty of available solar radiation for the dynamic energy demand in industrial production processes. This arises the need for dynamic simulations of energy systems to get a clear overview of the efficiency of ISHC systems and to see whether the solar system can generate the required temperature to run the plant, throughout its working time per day or its lifetime. To prove the feasibility and effectiveness, industry-specific or industrial process-specific lifecycle assessment could be carried out which will help to understand and commercialize the ISHC systems for saved fossil fuel consumption. Lifecycle costing analysis can also indicate manufacturers and consumers whether installing a solar process heating system can help their business or not. From such studies, numerous conclusions should be obtained as a result of the techno-economic analysis. With this, the following are the major future research scope questions:

- Is it viable to produce solar heat for industrial processes?

- In which industries is there the greatest potential and in which regions of the country?

- Which solar thermal technologies have the greatest potential?

- What is the percentage contribution of generated energy that a solar thermal system can offer?

- What are the impediments to large-scale deployment of solar thermal systems?

- What solutions would allow greater development of solar thermal systems?

\section{CONCLUSIONS}

In this review paper, major industrial groups and processes are studied globally for the identification of typical solar applications. Industrial groups and processes are mainly examined based on the demand temperature levels, solar technologies, and installed capacity. As a result, at least 624 SHIP including promising large-scale (up to $100 \mathrm{MW}_{\text {th }}$ ) plants and 1350 solar cooling systems most of them in small and medium capacities $(<350 \mathrm{~kW})$ are in operation. The food and beverage industry is ranked at the top with 33 plants in operation and an installed capacity of 104

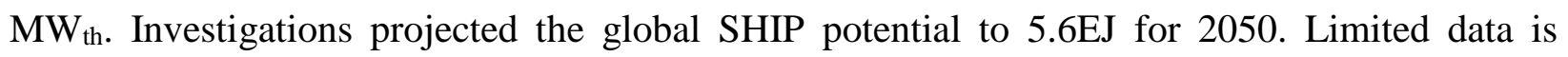
available for solar cooling installation and potential. These results indicate the potential to every country within the same industry type along with similar weather and economic conditions. As part of this, though there are no considerable developments in ST utilization, the paper has presented the conditions in Ethiopia for comparison. Thus, given the presence of many low to 
medium-temperature industrial processes, there are ample opportunities for ISHC systems integration. It is believed that the current scenario of solar system installation needs to be changed and there should be a need to consider ISHC not only as an integral part of new-build capacity but also as part of the existing capacity. Hence, this paper will certainly be a valuable resource to pay more attention to the long-term economic and ecological advantages that should outnumber equally, so that solar energy would be given a chance even if the initial costs may not be so favorable. To utilize the potential, further research and development on effective use of solar energy for industries become increasingly important as it is both the most challenging and the most important segment.

\section{ACKNOWLEDGEMENTS}

The authors would like to acknowledge CoE in REWiSE project funding for the first author Ph.D. study leading to this article.

\section{CONFLICT OF INTERESTS}

No conflict of interests.

\section{REFERENCE}

Abdelaziz, E. A., Saidur, R \& Mekhilef, S. 2010. A review on energy saving strategies in industrial sector. Renewable and Sustainable Energy Rev., 15: 150-168 (doi: 10.1016/j.rser.2010.09.003).

ABPS. 2011. Market Assessment of SWH Systems in Industrial Sector. Report, Ministry of New and Renewable Energy, Govt of India. Retrieved- https:/www.solarthermalworld.org/ sites/default/files/Report_Market_Assessment_of_SWH_in_Industrial_Sector.pdf.

Alemu, M. 2017. Study on Blackouts of Ethiopian Electric Power Network and Identification of System Vulnarabilities. Retrieved-http://etd.aau.edu.et/bitstream/handle/123456789/15216/ MogesAlemu.pdf?sequence $=1$ \&isAllowed $=\mathrm{y}$.

Alkilani, M. M., Sopian, K., Alghoul, M. A., Sohif, M \& Ruslan, M. H. 2011. Review of solar air collectors with thermal storage units. Renewable and Sustainable Energy Reviews, 15(3): 1476-1490 (doi: 10.1016/J.RSER.2010.10.019).

bp. (n.d.). Industry | Energy economics | Home. Retrieved from https://www.bp.com/en/global/ corporate/energy-economics/energy-outlook/demand-by-sector/industry.html.

Batidzirai, B., Lysen, E. H., van Egmond, S \& van Sark, W. G. J. H. M. 2009. Potential for solar 
water heating in Zimbabwe. Renewable and Sustainable Energy Reviews, 13(3): 567-582 (doi:10.1016/j.rser.2008.01.001).

Ben Hassine, I., Helmke, A., Heß, S., Krummenacher, P., Muster, B., Schmitt, B., Schnitzer, H., Brunner, C., Calderoni, M., Lauterbach, C., Mauthner, F., Pelloux-Payer, S., Reay, D \& Seidler, D. 2014. IEA SHC Task 49 Solar Process Heat for Production and Advanced Applications Deliverable B2 SolarPaces Annex IV. Retrieved from http://task49.ieashc.org/Data/Sites/7/150218_iea-task-49_d_b2_integration_guideline-final.pdf.

Benli, H. 2016. Potential application of solar water heaters for hot water production in Turkey. Renewable and Sustainable Energy Reviews, 54: 99-109 (doi:10.1016/j.rser.2015.09.061).

Byrne, J. 2010. World solar energy review: technology market and polices. Retrieved from http://ceep.udel.edu.

Chu, Y. 2011. Review and Comparison of Different Solar Energy Technologies. Global Energy Network Institute, August, 56 (doi: 10.1002/ejoc.201200111).

DeWinter, F. 1990. Solar collectors, energy storage, and materials. MIT Press. Retrieved from https://mitpress.mit.edu/books/solar-collectors-energy-storage-and-materials.

Diefenderfer, J., assumptions Vipin Arora, M \& Singer, L. E. 2016. International Energy Outlook 2016 Liquid fuels. Doel Eia-0484, 202-586. Retrieved from https://www.eia.gov/outlooks/ieo/pdf/0484(2016).pdf.

EECA. (n.d.). Energy Audit Standard for Process Heat Systems. 1-55. Retrieved from https://www.emanz.org.nz/sites/default/files/data/Directory/Process_Heat_Systems_Audi t_Std_V1.pdf.

Eia. 2014. Annual Energy Outlook 2014. Retrieved from www.eia.gov/analysis/modeldocumentation.cfm.

Eisentraut, A \& Brown, A. 2014. Heating without global warming - Market Developments and Policy Considerations for Renewable Heat. IEA, 92. Retrieved from https://www.iea.org/publications/freepublications/publication/FeaturedInsight_HeatingW ithoutGlobalWarming_FINAL.pdf.

Encyclopedia. (n.d.). Industry - Ethiopia - future, sector. Retrieved from https://www.nationsencyclopedia.com/Africa/Ethiopia-INDUSTRY.html.

Energypedia. 2013. Ethiopia Energy Situation - energypedia.info. Retrieved from https://energypedia.info/wiki/Ethiopia_Energy_Situation. 
Eshetie, T. 2018. Ethiopia's Manufacturing Industry Opportunities, Challenges and Way Forward: A Sectoral Overview. Novel Techniques in Nutrition \& Food Science, 2(2) (doi: 10.31031/ntnf.2018.02.000532).

ESTIF. 2006. European Solar Thermal Industry Federation. Retrieved from http://www.estif.org/fileadmin/estif/content/policies/downloads/D23-solar-industrialprocess-heat.pdf.

Ethio-Resource-Group. 2012. Solar energy vision for Ethiopia Opportunities for creating a photovoltaic industry in Ethiopia. Retrieved from www.isei.org.

FDRE, F. D. R. of E. M. of W. I. and E. 2013. Updated Rapid Assessment and Gap Analysis on Sustainable Energy for All. Retrieved from https://www.se4allafrica.org/fileadmin/uploads/se4all/Documents/Country_RAGAs/MWH_-_UpdatedRapid_Gap_Analysis.pdf.

Faninger, G. 2010. The Potential of Solar Heat in the Future Energy System. 1-20. Retrieved from https://www.aee-intec.at/0uploads/dateien868.pdf.

Fisch, M. N \& Huckemann, V. 2006. 4.3 Nonfocusing solar heat collection (including seasonal heat storage). In Renewable Energy (pp. 304-333). Springer Berlin Heidelberg (doi: 10.1007/10858992_12).

Gautam, A., Chamoli, S., Kumar, A \& Singh, S. 2017. A review on technical improvements, economic feasibility and world scenario of solar water heating system. Renewable and Sustainable Energy Reviews, 68: 541-562 (doi: 10.1016/j.rser.2016.09.104).

Gebreeyesus, M. 2013. Industrial Policy and Development in Ethiopia: Evolution and Current Performance. WIDER Working Paper, 6.

Gross, P \& Otis, P. 2016. Industrial sector energy consumption. In: International Energy Outlook 2016 (pp. 113-126). Retrieved from https://www.eia.gov/outlooks/ieo/pdf/industrial.pdf.

Hasanuzzaman, M., Rahim, N. A., Hosenuzzaman, M., Saidur, R., Mahbubul, I. M \& Rashid, M. M. 2012. Energy savings in the combustion based process heating in industrial sector. Renewable and Sustainable Energy Reviews, 16(7): 4527-4536 (doi: 10.1016/J.RSER.2012.05.027).

Henkel, E. T. 2005. New Solar Thermal Energy Applications for Commercial, Industrial, and Government Facilities. Energy Engineering, 102(2): 39-58 (doi: 10.1080/01998590509509425). 
Hoffmann, S \& Kogler, K, K. I. 2014. Market study of Solar Thermal Energy for Industrial / Commercial Use in Pakistan, Egypt and Morocco, IFC, International Finances Corp. Washington. Retrieved from https://www.solarthermalworld.org/sites/default/files/news /file/ 2015-02-27/ifc_study_executive_summary.pdf.

Hwang, Y., Radermacher, R., Alili, A. Al \& Kubo, I. 2008. Review of Solar Cooling Technologies. HVAC\&R Research, 14(3), 507-528. doi: 10.1080/10789669.2008.10391022

IPCC. 2001. TECHNICAL SUMMARY CLIMATE CHANGE 2001: MITIGATION A Report of Working Group III of the Intergovernmental Panel on Climate Change Lead Authors: Review Editor: Retrieved from https://www.ipcc.ch/site/assets/uploads/2018/03/ WGIII_TAR_full_report.pdf

Indexmundi. 2019. Ethiopia Economy Profile 2018. 8-11. Retrieved from https://www.indexmundi.com/ethiopia/economy_profile.html

Islam, M. P \& Morimoto, T. 2018. Advances in low to medium temperature non-concentrating solar thermal technology. Renewable and Sustainable Energy Reviews, 82, 2066-2093. doi: 10.1016/J.RSER.2017.08.030.

Kalogirou, S. 2003. The potential of solar industrial process heat applications. Applied Energy, 76(4): 337-361 (doi: 10.1016/S0306-2619(02)00176-9).

Lauterbach, C., Schmitt, B., Jordan, U \& Vajen, K. 2012. The potential of solar heat for industrial processes in Germany. Renewable and Sustainable Energy Reviews, 16(7): 5121-5130. doi: 10.1016/j.rser.2012.04.032.

Mekhilef, S., Saidur, R \& Safari, A. 2011a. A review on solar energy use in industries. Renewable and Sustainable Energy Reviews, 15(4): 1777-1790 (doi: 10.1016/j.rser.2010.12.018).

Mekhilef, S., Saidur, R \& Safari, A. 2011b. A review on solar energy use in industries. Renewable and Sustainable Energy Reviews, 15(4): 1777-1790 (doi: 10.1016/j.rser.2010.12.018).

Metz, B., Meyer, L \& Bosch, P. 2007. Climate change 2007 mitigation of climate change. Climate Change 2007 Mitigation of Climate Change, Vol. 9780521880 (doi: 10.1017/CBO9780511546013).

MoFED. 2014. Federal Democratic Republic of Ethiopia Growth and Transformation Plan. $l l($ November 2010). Retrieved from http://extwprlegs1.fao.org/docs/pdf/eth144893.pdf

MoI. 2017. Investment Opportunity in Manufacturing Industry Investment Research, Monitoring and Support Directorate. 1-34. Retrieved from https://isid.unido.org/files/Forum- 
AIFE2/4. Investment Opportunity in Manufacturing Industry.docx.pdf

NASA. 2016. Earth's Energy Budget Poster. Retrieved from https://scienceedu.larc.nasa.gov/energy_budget/

Nathan, A. J \& Scobell, A. 2012. How China sees America? Foreign Affairs, 91(5): 1689-1699 (doi: 10.1017/CBO9781107415324.004).

Pirasteh, G., Saidur, R., Rahman, S. M. A \& Rahim, N. A. 2014. A review on development of solar drying applications. Renewable and Sustainable Energy Reviews, 31: 133-148 (doi: 10.1016/J.RSER.2013.11.052).

Platzer, W. 2015. Potential studies on solar process heat worldwide Task 49/IV. 17. Retrieved from http://task49.iea-shc.org/data/sites/1/publications/151031_IEA_Task49_Deliverable_ C5_ Potential studies.pdf

Ramos, C., Ramirez, R \& Beltran, J. 2014. Potential Assessment in Mexico for Solar Process Heat Applications in Food and Textile Industries. Energy Procedia, 49: 1879-1884 (doi: 10.1016/J.EGYPRO.2014.03.199).

Rashad, M., El-Samahy, A. A., Daowd, M \& Amin, A. M. A. 2013. A comparative Study on Photovoltaic and Concentrated Solar Thermal Power Plants. Recent Advances in Environmental and Earth Sciences and Economics, 167-173. Retrieved from https://pdfs.semanticscholar.org/9952/6eca95b0f989ccd670445d46cc229f6f564a.pdf.

REEP. (n.d.). Ethiopia Infrastructure, Power \&amp; Energy Investment Summit 2014| REEEP. Retrieved from https://www.reeep.org/events/ethiopia-infrastructure-power-energyinvestment-summit-2014

Saidur, R. 2010. A review on electrical motors energy use and energy savings. Renewable and Sustainable Energy Reviews, 14(3): 877-898 (doi: 10.1016/j.rser.2009.10.018)

Saidur, R., Rahim, N. A., Ping, H. W., Jahirul, M. I., Mekhilef, S \& Masjuki, H. H. 2009. Energy and emission analysis for industrial motors in Malaysia. Energy Policy, 37(9): 3650-3658. Retrieved from https://ideas.repec.org/a/eee/enepol/v37y2009i9p3650-3658.html

Schweiger, H., Mendes, J. F., Carvalho, M. J., Hennecke, K \& Krüger, D. 2015a. Solar heat for industrial processes. Advances in Solar Energy: An Annual Review of Research and Development in Renewable Energy Technologies, 17: 216-260 (doi: 10.4324/9781315793221-14).

Schweiger, H., Mendes, J. F., Carvalho, M. J., Hennecke, K \& Krüger, D. 2015b. Solar heat for 
industrial processes. Advances in Solar Energy: An Annual Review of Research and Development in Renewable Energy Technologies, 17: 216-260 (doi: 10.4324/9781315793221-14).

Sharma, A., Tyagi, V. V., Chen, C. R \& Buddhi, D. 2009. Review on thermal energy storage with phase change materials and applications. Renewable and Sustainable Energy Reviews, 13(2): 318-345 (doi: 10.1016/J.RSER.2007.10.005).

Sharma, C., Sharma, A. K., Mullick, S. C \& Kandpal, T. C. 2014. Assessment of solar thermal power generation potential in India. Renewable and Sustainable Energy Reviews, 42: 902912 (doi: 10.1016/j.rser.2014.10.059).

Sharma, A. K., Sharma, C., Mullick, S. C \& Kandpal, T. C. 2015. Potential of Solar Energy Utilization for Process Heating in Paper Industry in India: A Preliminary Assessment. Energy Procedia, 79: 284-289 (doi: 10.1016/J.EGYPRO.2015.11.486).

Sharma, A. K., Sharma, C., Mullick, S. C \& Kandpal, T. C. 2017a. Potential of solar industrial process heating in dairy industry in India and consequent carbon mitigation. Journal of Cleaner Production, 140: 714-724 (doi: 10.1016/J.JCLEPRO.2016.07.157).

Sharma, A. K., Sharma, C., Mullick, S. C \& Kandpal, T. C. 2017b. GHG mitigation potential of solar industrial process heating in producing cotton based textiles in India. Journal of Cleaner Production, 145: 74-84 (doi: 10.1016/J.JCLEPRO.2016.12.161).

SHIP. (n.d.). Bomans Lackering | Solar Heat for Industrial Processes (SHIP) Plants Database. Ship-Plants.Info. Retrieved from http://ship-plants.info/

Shirazi, A., Taylor, R. A., Morrison, G. L \& White, S. D. 2018. Solar-powered absorption chillers: A comprehensive and critical review. Energy Conversion and Management, 171: 59-81 (doi: 10.1016/J.ENCONMAN.2018.05.091).

Smil, V. 1991. General energetics : energy in the biosphere and civilization. Wiley. Retrieved from https://www.worldcat.org/title/general-energetics-energy-in-the-biosphere-andcivilization/oclc/645759899? referer=di\&ht=edition

SOLARGIS. 2018. Solar resource maps and GIS data for 180+ countries | Solargis. doi: 10.1016/j.puhe.2008.10.012

Statista. 2018. Ethiopia - share of economic sectors in the gross domestic product 2018| Statista. Retrieved from https://www.statista.com/statistics/455149/share-of-economic-sectors-inthe-gdp-in-ethiopia/ 
Taibi, E., Gielen, D \& Bazilian, M. 2012. The potential for renewable energy in industrial applications. Renewable and Sustainable Energy Reviews, 16(1): 735-744 (doi: 10.1016/j.rser.2011.08.039).

UNEP. 2015. Etiopia: Energy profile, Total energy production,Total energy consumption and Production (Issue Table 1). Retrieved from https://wedocs.unep.org/bitstream/handle/ 20.500.11822/20512/Energy_profile_Ethiopia.pdf?sequence=1\&isAllowed=y.

US DoE. 2015. Improving Process Heating System Performance - A Sourcebook for Industry. Industrial Technologies Program. Retrieved from https://www.nrel.gov/docs/ fy08osti/41589.pdf.

US EIA. 2013. International Energy Outlook 2013 - DOE/EIA-0484(2013). In Outlook 2013. Retrieved from www.eia.gov.

Vajen, K., Lauterbach, C \& Schmitt, B. 2012. International Conference on Solar energy for MENA region (INCOSOL). Retrieved from www.solar.uni-kassel.de.

Vannoni, C., Battisti, R \& Drigo, S. 2008. Task 33/IV-Potential for Solar Heat in Industrial Processes Potential for Solar Heat in Industrial Processes Task 33/IV-Potential for Solar Heat in Industrial Processes. Retrieved from http://task33.iea-shc.org/ Data/Sites/1/publications/task33-Potential_for_Solar_Heat_in_Industrial_Processes.pdf.

Vignarooban, K., Xu, X., Arvay, A., Hsu, K \& Kannan, A. M. 2015. Heat transfer fluids for concentrating solar power systems - A review. Applied Energy, 146: 383-396 (doi: 10.1016/J.APENERGY.2015.01.125).

Weiss, W \& Mauthner, F. 2011. Solar Heat Worldwide, Markets and contribution to the energy supply 2007. In IEA Solar Heating \& Cooling Programme. Retrieved from https://nachhaltigwirtschaften.at/resources/pdf/solarheat_ww.pdf?m=1469658718.

Weiss, W \& Spörk-Dür, M. 2018. Solar Heat Worldwide Detailed Market Figures 2016. 2018 Edition, Global Market Development and Trends in 2017. Retrieved from http://www.ieashc.org/Data/Sites/1/publications/Solar-Heat-Worldwide-2018.pdf.

World Energy. (2011). World energy outlook 2011 factsheet. International Energy Agency, 6 (doi: 10.1787/weo-2011-en).

Zalba, B., Marín, J. M., Cabeza, L. F \& Mehling, H. 2003. Review on thermal energy storage with phase change: Materials, heat transfer analysis and applications. Applied Thermal Engineering, 23(3): 251-283 (doi: 10.1016/S1359-4311(02)00192-8). 